ПРОБЛЕМА ПРОФЕСІЙНОЇ ПІДГОТОВКИ МАЙБУТНІХ ПРОВІЗОРІВ У КОНТЕКСТІ РОЗВИТКУ СУЧАСНОГО ІНФОРМАЦІЙНОГО СУСПІЛЬСТВА

\title{
THE PROBLEM OF PROFESSIONAL TRAINING OF FUTURE PROVIDERS IN THE CONTEXT OF THE DEVELOPMENT OF A MODERN INFORMATION SOCIETY
}

\begin{abstract}
у статті визначено роль інфрормаційнокомунікаційних технологій у розвитку сучасного інформаційного суспільства. Указано, які якості має бути наділений фахівець-провізор. Окрім фрахових знань, фрахівиям фрармацевтичної галузі потрібно бути здатними передбачати напрям соціальних змін, розви ток суспільства, а також добре орієнтуватися в етичних проблемах орармацевтичного ринку й фрармацевтичної діяльності, маркетингу. Проаналізовано вплив запровадження інновацій у вітчизняний освітній прочес. Визначено перспективи запровадження інфрормаційно-комунікаційних технологій в інтегрованих науково-виробничих комплексах для підготовки орармацевтичних кадрів. Розглянуто визначення інфрормаційної компетентності провізорів. Указано важливість фрормування інфрормаційної компетенції як основи фрормування професійних якостей. Інорормаційна компетениія є важливою складовою професійної компетентності провізорів, професійна діяльність яких пов'язана з постійним прийняттям рішень. Підготовка фрахівця в сучасних умовах відповідно до «Концепції розвитку фрармацевтичного сектору галузі охорони здоров'я України» (далі - Концепція) перетворюється на навчання впродовж життя. Саме тому майбутньому провізору впродовж навчання бажано засвоїти різноманітні способи та форми роботи, що допоможуть йому надалі продовжити освіту й самоосвіту. Розглянуто умови, які забезпечать формування інфрормаційно-комунікаційної компетентності майбутніх провізорів. Такими умовами формування фрахівця фрармачевтичної галузі $\epsilon$ культурологічний підхід до використання інформаційних технологій у професійній освіті, взаємодія з роботодавцями й професійна мобільність майбутніх провізорів. Класифріковано компоненти інфрормаційнокомунікаційної компетентності як мотиваиійний, когнітивний, діяльнісний. Автори підкреслюють важливість ефрективного вміння знаходити, опрацьовувати, представляти інфрормацію в різних орормах з використанням інформаційно-комунікаційних технологій з метою якісної підготовки провізорів у сучасних умовах. Виокремлено специфрічні принципи формування інфрормаційно-комунікаційної компетентності майбутніх провізорів.

Ключові слова: розвиток інсрормаційнокомунікаційних технологій, освітній процес, провізор, профресійна підготовка.
\end{abstract}

The article defines the role of information and communication technology in the development of the modern information society. It is indicated what qualities a specialist pharmacist should be endowed with. In addition to the possession of professional knowledge, pharmaceutical specialists should be able to predict the direction of social changes, the development of society, and also be well-versed in the ethical problems of the pharmaceutical market and pharmaceuti$\mathrm{cal}$ activities, marketing. The influence of the introduction of innovations in the domestic educational process is analyzed. The prospects for the implementation of information and communication technologies in integrated research and production complexes for the training of pharmaceutical personnel are determined. The definition of information competence of pharmacists is considered. The importance of the formation of information competence as the basis for the formation of professional qualities is indicated. The possession of information competence is an important component of the professional competence of pharmacists, whose professional activity is associated with constant decision-making. According to the "Concept for the Development of the Pharmaceutical Sector, Ukraine's healthcare" was organized, training a specialist in modern conditions is lifelong learning. That is why it is advisable for the future pharmacist to master various methods and forms of work during training, which allows him to continue his education and self-education in the future. The conditions that will ensure the formation of information and communication competence of future pharmacists are considered. Such conditions for the formation of a specialist in the pharmaceutical industry are a cultural approach to the use of information technology in vocational education, interaction with employers and professional mobility of future pharmacists. The components of information and communication competence are classified as motivational, cognitive, and activity. The authors emphasize the importance of effective ability to find, process, present information in various forms using information and communication technologies with the aim of high-quality training of pharmacists in modern conditions. The specific principles of the formation of information and communication competence of future pharmacists are highlighted.

Key words: development of information and communication technologies, educational process, pharmacist, professional training.
Льцент кафедри біофізики університету імені Данила Галицького ців, які, окрім ґрунтовних орахових знань, мають такі якості, як здатність передбачити напрямок соціальних змін, розвиток суспільства, а також добре орієнтуватися в етичних проблемах орармацевтичного ринку й фрармацевтичної діяльності, маркетингу. Тому неперервний професійний розвиток провізора в наданні якісної фрармацевтичної допомоги населенню стає все більш значним і необхідним. Забезпечення якісної допомоги громадянам зале-
Динамічне збільшення кількості інорормації в глобальному масштабі, розвиток інформаційних ресурсів та їх використання в усіх сорерах фрункціонування суспільства за допомогою інформаційнокомунікаційних технологій вказує на новий етап розвитку людства [1].

Сучасні тенденції соціальних змін вимагають присутності на фрармацевтичному ринку праці фрахів- 
жить від індивідуальної відповідальності провізорів, які, відповідно до Концепції неперервного професійного розвитку, відповідають за систематичне підтримання, оновлення фрахових знань, навичок і вмінь для забезпечення їхньої постійної компетентності як фрахівців протягом усієї кар'єри [2, 3].

Реалізація Концепції здійснюється за допомогою таких фрорм, як формальна, неформальна та інорормальна. Невіддільними елементами неперервного профресійного розвитку $€$ самоосвіта, самопідготовка й навчання на практиці.

Окрім того, профресійна діяльність фрахівцівпровізорів передбачає залучення їх до процесу лікування, який полягає у виборі та його обґрунтуванні необхідних лікарських засобів і медичних препаратів, консультування й навчання пацієнтів. Оскільки фрармакотерапія пов'язана з певним ризиком, наприклад виникненням побічних ефектів, зумовлених дією лікарського засобу, то провізори беруть участь у моніторингу й оцінці результатів лікарської терапії, несуть відповідальність за поради або рекомендації, що надають пацієнту.

В умовах сьогодення спостерігається зростання випадків самолікування громадян. Причинами такого явища $€$ обмежений доступ до сімейного лікаря, агресивна маркетингова політика фрармацевтичних компаній і неконтрольоване рекламування лікарських засобів і медичних препаратів. За таких умов провізор має значний вплив на лікування людей. Отже, якість підготовки фахівця $€$ важливим чинником всієї системи підготовки майбутніх орармацевтичних працівників.

Аналіз останніх досліджень і публікацій. Упровадження інорормаційних технологій у всі галузі життєдіяльності людини, широке використання комп'ютерної техніки й інформаційно-комунікаційних технологій постійно підвищують нові стандарти підготовки фрахівців. У тексті «Національної доктрини розвитку освіти України у XXI столітті» визначено пріоритети державної політики в розвитку освіти, одним із яких $є$ «розробка й запровадження освітніх інновацій, інформаційних технологій» [4].

Фармацевтична галузь зараз на етапі динамічного розвитку. В Україні створені основні передумови для наступного етапу розвитку фрармацевтичної галузі, однією з яких є забезпечення ефрективної й доступної фрармакотерапії [5].

Перспективами розвитку визначено модернізацію структури фрармацевтичного виробництва на основі іï оптимізації, впровадження інноваційної моделі швидкого економічного зростання, перспективний розвиток конкурентоспроможних високоефективних технологій виробництва, підвищення рівня якісних показників рентабельності виробництва.

Тому розвиток нових технологій виробництва вимагає зосередження зусиль як на рівні держави, так і на рівні місцевого самоуправління утворенню інтегрованих науково-виробничих комплексів [6].

Виділення не вирішених раніше частин загальної проблеми. Значення інфрормаційно-комунікаційних технологій у фрормуванні професійних якостей майбутніх провізорів визначено такими нормативно-правовими документами, як Закон України «Про освіту», Закон України «Про вищу освіту», Закон України «Про наукову і науковотехнічну діяльність», Державна національна програма «Освіта» («Україна XXI століття»), «Про вищу освіту» (2014) та інші нормативно-правові акти у сфері освіти. Проте умови й моделі фрормування інфрормаційно-комунікаційних технологій розглянуті недостатньо й вимагають ретельнішого дослідження.

Метою статті $€$ аналіз наукових джерел 3 питань якості професійної підготовки майбутніх фрармацевтичних працівників в умовах запровадження інформаційно-комунікаційних технологій.

Виклад основного матеріалу. Неперервний розвиток суспільства, створення й упровадження в щоденне життя нових наукомістких технологій безпосередньо впливає на когнітивний розвиток людини XXI століття. Стрімке збільшення обсягу інорормації, яке спостерігається з середини минулого століття, зумовлене великою кількістю чинників, серед яких виокремимо доступність джерел інорормації, шляхів іiї зберігання й поширення. Зростання кількості інорормації вимагає перегляду уявлень про традиційну систему підготовки фрахівців. Оскільки актуальність отриманих знань молодих фрахівців втрачається в середньому за 5 років, тому постала проблема неперервного навчання або навчання протягом усього життя. Необхідність пошуку нової інфрормації, розширення фрахових знань вимагає широкого впровадження сучасних методів навчання. Вимога сьогодення в підготовці майбутніх фрахівців-провізорів обумовлена змінами в системі вищої освіти, зокрема в галузі охорони здоров'я України, прогресом світової фрармацевтичної й медичної науки, змінами на ринку праці [5].

Одним 3 найважливіших інноваційних напрямів розвитку системи удосконалення фрармацевтичних кадрів є відкрита освіта. Відкрита освіта індивідуально орієнтована, вона спрямована на створення відповідних умов для особи, яка навчається, для проєктування й реалізації власних індивідуальних освітніх траєкторій [7]. Підготовка фрахівців у сучасних умовах перетворюється на навчання впродовж життя. Саме тому майбутньому провізорові впродовж навчання бажано освоїти різноманітні способи й форми роботи, що допоможуть йому й далі продовжити освіту й самоосвіту.

Для реалізації окремих напрямів підготовки кадрів фармацевтичної галузі необхідно поставити педагогічні умови, які забезпечать фрормування 
компетенцій у висококваліфікованих фрахівців. Такими умовами фрормування фрахівця-провізора $€$ культурологічний підхід до використання інорормаційних технологій у професійній освіті, взаємодія 3 роботодавцями й професійна мобільність майбутніх фрармацевтів-провізорів, урахування впливу суспільства й фармацевтичної галузі. За таких педагогічних умов підвищиться розвиток інорормаційно-комунікаційної компетентності майбутніх провізорів.

У працях В.А. Дарлінгера, П.В. Беспалова, В.Л. Голунова, В.В. Недбай знаходимо кілька визначень «інфрормаційної компетентності». Зокрема, на думку Н. Баловсяк, інформаційна компетентність сорормована як новий напрям під впливом нових інформаційних технологій і створення електронних інфрормаційних технологій i складається з таких компонентів: інформаційного, комп'ютерного або комп'ютерно-технологічного та процесуально-діяльнісного [8].

Напрям реалізації компетентнісного підходу у вищій фрармацевтичній освіті простежується порівняно недавно. Але попри достатній обсяг теоретичних і практичних досліджень у цьому векторі інорормаційна компетентність здебільшого розглядається тільки в контексті використання інформаційних технологій у навчально-практичній діяльності майбутніх фрахівців. Проте інфрормаційну компетентність провізорів варто розглядати як сукупність їхніх професійних якостей, в основі яких лежать здібності, знання, вміння й навички в галузі освоєння нових інфрормаційних технологій, а також досвід їх застосування в професійній діяльності.

Використання інформаційних технологій у фрармацевтичній галузі передбачає такі дії:

- підбір оптимальних видів лікарських рослин і їх композицій для лікування конкретного захворювання;

- визначення показань і протипоказань до призначення лікарської рослинної сировини й фрітопрепаратів;

- пошук замінників лікарських рослин іншими в разі прояву небажаних побічних еоректів;

- виявлення термінів заготівлі або періодів обробітку;

- роботу в інорормаційних відділах фрірмвиробників і спеціалізованих господарств з вирощування лікарських рослин;

- тиражування інформації про лікарські рослини, виключені 3 національних реєстрів через несприятливу побічну дію на організм людини.

Володіння цими технологіями майбутніми провізорами, професійна діяльність яких пов'язана 3 постійним прийняттям рішень, є важливою складовою професійної компетентності [9].

Нині без знань інфрормаційних технологій неможливий розвиток у жодній з галузей, зокрема й у фрармації. Тому під час підготовки фрармацевтичних кадрів потрібно оптимально підбирати засоби й методи навчання, фрорми організації навчального процесу відповідно до цілей і завдань навчання, а саме з використанням інфрормаційнокомунікаційних технологій.

Формування інфрормаційно-комунікаційної компетентності майбутніх провізорів містить такі компоненти, як мотиваційний, когнітивний, діяльнісний [10].

Мотиваційний компонент стимулює й закріплює стійке позитивне ставлення майбутніх фрахівців до професійної діяльності, передбачає формування особистісної мотиваційної налаштованості на таку діяльність, в якій закладено потреби, інтереси, бажання вдосконалювати свої знання й уміння та прагнути до самореалізації й самовдосконалення.

Когнітивний компонент спрямовує підготовку фрахівців на опанування системою необхідних для здійснення професійної діяльності теоретичних і практичних знань, а також фрормування у нього профресійно значущих понять, уявлень, якостей. Цей компонент забезпечує спроможність провізорів ефективно діяти.

Діяльнісний компонент забезпечує майбутнім фрахівцям опанування методами й прийомами профресійної діяльності, необхідними для досягнення її проміжних і кінцевих цілей [10].

Отже, виділені компоненти фрормування інформаційно-комунікаційної компетентності сприяють забезпеченню безперервної освіти майбутніх провізорів.

Висновки. Отже, фрахівці які працюють у фрармацевтичній галузі, мають володіти інтегрованими знаннями, у тому числі й інформаційно-комунікаційними технологіями. Необхідність якісної підготовки провізорів у сучасних умовах вимагає вміння ефективної роботи з інфрормацією в усіх ії формах, з сучасними комп'ютерними засобами й програмним забезпеченням, здатності застосовувати сучасні засоби інформаційних і комп'ютерних технологій в роботі з інформацією та розв'язання фрахових задач. Виокремлено специфрічні принципи фрормування інформаційно-комунікаційної компетентності майбутніх провізорів.

\section{БІБЛІОГРАФІЧНИЙ СПИСОК:}

1. Петрухно Ю.Є. Інформаційне суспільство: поняття, основні складові, характеристика. Вісник ОНУ. Серія «Бібліотекознавство, бібліографознавство, книгознавство». 2014. Т. 19 (1). С. 127-133.

2. Громовик Б.П., Горілик А.В. Неперервна фрармацевтична освіта в Україні: науково-методичні аспекти управлінсько-економічної підготовки : монографрія. Львів : РАСТР-7, 2012. 166 с.

3. Михайлюк М. Реформування вищої медичної освіти в Україні. Збірник наукових праць А'ОГО . 2020. C. 22-24. URL: https://ojs.ukrlogos.in.ua/ index.php/logos/article/view/656 (дата звернення 18.02.2020). 
4. Національна доктрина розвитку освіти України у XXI столітті / Міністерство освіти і науки України, Академія педагогічних наук України. Київ : Шкільний світ, 2001. 24 с.

5. Про затвердження Концепції розвитку фармацевтичного сектору галузі охорони здоров'я України на 2011-2020 р. : Наказ Міністерства охорони здоров'я України від 13 вересня 2010 р. № 769. URL: https:// zakon.rada.gov.ua/rada/show/v0769282-10 (дата звернення 18.02.2020).

6. Бачення 2020: план дій у сорері розвитку фрармацевтичного сектору в Україні. URL:http://www.niss. gov.ua/articles/846 (дата звернення 18.02.2020).

7. Бех, В., Бех Ю. Фантом освіти інорормаційної доби: погляд у XXI століття. Збірник наукових праць А'ОГО 2020. C. 49-55. URL:https://doi.org/10.36074/24.01.2020. V2.16 (дата звернення 18.02.2020).

8. Баловсяк Н.Х. Структура та зміст інфрормаційної компетентності майбутнього спеціа- ліста. Науковий часопис Національного педагогічного університету імені М.П. Драгоманова. Серія № 2 «Комп'ютерно-орієнтовані системи навчання». № 4 (11). 2006. URL:http://enpuir.npu.edu. ua/bitstream/123456789/888/1/30.pdf (дата звернення 18.02.2020).

9. Іванькова Н.А. Особливості фрормування інфрормаційно-комунікаційної компетентності провізораінтерна в системі вищої фрармацевтичної освіти. Актуальні питання дистанційної освіти та телемедицини 2018 : матеріали Всеукр. наук.-метод. відеоконфр. $з$ міжнар. участю, Запоріжжя, 25-26 квітня 2018 р. Запоріжжя : ЗДМУ, 2018. С. 40-41.

10. Солонська А.А. Модель фрормування інфрормативної компетентності у студентів медичних закладів вищої освіти в умовах дистанційного навчання. Науковий вісник Мелітопольського державного педагогічного університету. Серія «Педагогіка». Т. 1. № 22. 2019. C. 80-86. 